\title{
Levels of YKL-40 in pleural effusion and blood from patients with pleuritis
}

\author{
Yasemin SÖYLER ${ }^{\mathbf{1}}$ (ID) \\ Oya $\operatorname{KAYACAN}^{2}$ (ID) \\ Abbas TANER $^{3}(I D)$
}

\footnotetext{
${ }^{1}$ Clinic of Chest Diseases, Health Sciences University, Ataturk Thoracic Diseases and Chest Surgery Training and Research Hospital, Ankara, Turkey

1 Sağlık Bilimleri Üniversitesi, Ankara Atatürk Göğüs Hastalıkları ve Göğüs Cerrahisi Eğitim ve Araştırma Hastanesi, Göğüs Hastalıkları Kliniği, Ankara, Türkiye

2 Department of Chest Diseases, Faculty of Medicine, Ankara University, Ankara, Turkey

${ }^{2}$ Ankara Üniversitesi Tıp Fakültesi, Göğüs Hastalıkları Anabilim Dalı, Ankara, Türkiye

${ }^{3}$ Clinical Microbiology Laboratory, Koru Hospitals, Ankara, Turkey

${ }^{3}$ Koru Hastaneleri, Klinik Mikrobiyoloji Laboratuvarı, Ankara, Türkiye
}

* Çalışmamız Ankara Üniversitesi Tıp Fakültesi Gögüus Hastalıkları Anabilim Dalında yapılmış olup YKL-40 biyobelirtecinin kanda ve
plevra sıvısında ölçümleri Özel Koru Hastanesi Mikrobiyoloji Laboratuvarları'nda yapılmıştır. Bu çalışma 2016 yılında Türk Toraks
Derneği 19. kongresinde poster olarak sunulmuştur.

Cite this article as: Söyler Y, Kayacan O, Taner A. Levels of YKL-40 in pleural effusion and blood from patients with pleuritis. Tuberk Toraks 2020;68(3):268-277.

\section{Yazışma Adresi (Address for Correspondence)}

Dr. Yasemin SÖYLER

Sağlık Bilimleri Üniversitesi,

Ankara Atatürk Göğüs Hastalıkları ve

Göğüs Cerrahisi Eğitim ve Araştırma Hastanesi, Göğüs Hastalıkları Kliniği,

ANKARA - TÜRKIYE

e-mail: dryaseminsoyler@gmail.com

CCopyright 2020 by Tuberculosis and Thorax.

Available on-line at www.tuberktoraks.org.com

\section{ABSTRACT}

Levels of YKL-40 in pleural effusion and blood from patients with pleuritis

Introduction: In recent years, there have been a significant increase in the tests and biomarkers available for pleural fluid analysis. YKL-40 is one of the inflammatory biomarkers that is used for this purpose. The aim of our study is to assess the levels and diagnostic values of YKL-4O in patients with different types of pleural effusions (PE).

Materials and Methods: This was a prospective, observational and crosssectional study. Pleural and serum YKL-40 levels were measured using enzyme-linked immunosorbent assay in 119 patients with PEs, including 23 transudates $P E, 47$ malignant $P E, 26$ parapneumonic $P E$ (PPPE), 17 paramalignant PE (PME) and 6 tuberculous PE (TBPE).

Results: Median pleural YKL-40 level was higher in exudates $(390.3 \mathrm{ng} / \mathrm{mL})$ than in transudates $(369.5 \mathrm{ng} / \mathrm{mL})(p<0.02)$. For a cut-off level of $378 \mathrm{ng} / \mathrm{mL}$, it was found to predict exudates with $70 \%$ sensitivity and $64 \%$ specificity. [area under the curve $(A \cup C)=0.660, p=0.01]$. Median pleural YKL-40 level was highest in PMEs (407.1 ng/mL) and the lowest in transudates (369.5 $\mathrm{ng} /$ $\mathrm{mL}$ ) and high levels, with a cut-off value of $396 \mathrm{ng} / \mathrm{mL}$, differentiated PMEs from other subgroups with $65 \%$ sensitivity and $68 \%$ specificity. $(A \cup C=0.680$, $p=0.02)$. Median serum YKL-40 level was the highest in PPPEs $(351.4 \mathrm{ng} / \mathrm{mL})$ and the lowest in TBPEs $(114.2 \mathrm{ng} / \mathrm{mL})(p=0.01)$. For a cut-off level of 284 
$\mathrm{ng} / \mathrm{mL}$, it differentiated PPPEs from TBPEs with $61 \%$ sensitivity and $100 \%$ specificity $(A \cup C=0.830, p=0.01)$. In TBPEs, pleural/serum YKL-40 ratio was strongly related with pleural $A D A(r=1, p=0.04)$.

Conclusion: Pleural YKL-40 may be useful for differentiating exudates and detecting PMEs. Serum YKL-40 may be good diagnostic biomarker for differentiating PPPES and TBPEs. Additionally, measuring serum and pleural YKL-40 and pleural ADA may be reliable way to diagnose TBPEs.

Key words: YKL-40; pleural effusion; biomarker; exudate; transudate

\section{ÖZ}

\section{Plörezili olguların plevra sıvısında ve kanda YKL-40 düzeyinin tanısal rolü}

Giriş: Plevral efüzyon (PE) yaygın bir patolojidir. Son yıllarda plevra sıvı analizi için test ve biyobelirteçlerde artış olmuştur. YKL-40 bu amaçla kullanılan biyobelirteçlerden biridir. Çalışmamızın amacı farklı nedenlere bağlı plevral sıvı gelişen hastalardaki YKL-40'ın tanısal düzeylerini değerlendirmektir.

Materyal ve Metod: 23 transüda PE (TPE), 47 malign PE (MPE), 26 parapnömonik PE (PPPE), 17 paramalign PE (PME) ve 6 tüberküloz PE (TBPE) olan 119 hastanın dahil edildiği prospektif, gözlemsel ve kesitsel bir çalışma yapıldı. Hastaların kanda ve plevra sIVIsında enzim bağlı immünosorbent tetkiki ile YKL-40 düzeyleri ö/çüldü.

Bulgular: Median plevral YKL-40 düzeyi eksüda sıvılarda (390.3 ng/mL) transüda sıvılardan (369.5 ng/mL) yüksekti (p< 0.02). Eşik değeri $378 \mathrm{ng} / \mathrm{mL}$ belirlendiğinde \%70 duyarlıık, \%64 özgüllük ile yüksek değerler eksüda sıvıları saptadı [eğri altında kalan alan $(A \cup C)=0.660, p=0.01]$. Median plevral YKL-40 düzeyi en yüksek PME'lerde (407.1 ng/mL), en düşük TPE'lerde saptandı (369.5 ng/ $m L)(p=0.02)$. Eşik değeri $396 \mathrm{ng} / \mathrm{mL}$ alındığında, \%65 duyarlıık, \%68 özgüllük ile yüksek değerler PME'leri işaret ediyordu (AUC= $0.680 \mathrm{p}=0.02)$. Median serum YKL-40 düzeyi en yüksek PPPE'lerde $(315 \mathrm{ng} / \mathrm{mL})$ ve en düşük TBPE'lerde (114.2 $\mathrm{ng} / \mathrm{mL}) \mathrm{bulundu}$ ( $p=0.01)$. Eşik değeri $284 \mathrm{ng} / \mathrm{mL}$ alındığında, \%61 duyarlıık, \% 100 özgüllük ile PPPE'leri TBPE'lerden ayırdı $(A U C=0.830, p=0.01)$. Ayrıca TBPE'lerde plevra/serum YKL-40 oranı plevra adenozin deaminaz (ADA) düzeyi ile çok kuvvetli korelasyon gösterdi $(r=1, p=$ 0.04).

Sonuç: Bu çalışma plevral YKL-40'ın, eksüda sıvıları transüda sıvılardan ayırt etmede ve PME'leri tespit etmede kullanılabileceğini, serum YKL-4O'ın, PPPE'leri ve TBPE'leri ayırt etmek için iyi bir biyobelirteç olabileceğini düşündürmektedir. Ek olarak, serum ve plevral YKL-40'ın ve plevra ADA'nın birlikte ölçülmesi TBPE'leri teşhis etmek için güvenilir bir yol olabilir.

Anahtar kelimeler: YKL-40; plevral effüzyon; biyomarker; eksüda; transüda

\section{INTRODUCTION}

Pleural effusion (PE) is one of the most common manifestation of pleural diseases. The most common causes for PEs are congestive heart failure, infections (e.g. pneumonia, tuberculosis), malignancy and pulmonary embolism. The definite diagnosis of the PE is essential for the proper treatment of the disease and it can be a dilemma for the clinician. In recent years, there have been a significant increase in the tests and biomarkers available for pleural fluid analysis. YKL40 (Chitinase 3 -like 1 protein) is one of the diagnostic inflammatory biomarkers.

YKL-40 is a member of the 18-glycosylhydrolase family, a protein family that also includes chitinases and chitinase-related proteins. The protein is termed YKL40 after its molecular weight $(40 \mathrm{kDa})$ and the one letter code for its three $\mathrm{N}$-terminal amino acids, namely tyrosine $(\mathrm{Y})$, lysine $(\mathrm{K})$, and leucine $(\mathrm{L})(1)$. The physiologic function of YKL-40 is unknown; however, the pattern of its expression in normal and disease states suggests that it plays a role in the degradation of extracellular matrix or tissue inflammation (2).
YKL-40 has also been shown to be associated with lung injury pathogenesis contributing to inflammation, remodeling and cellular proliferation (3).

Currently, only 5 clinical studies have examined the level of YKL-40 in pleural fluid and serum in several pleuropulmonary diseases (4-8). The aim of our study was to assess the level and diagnostic value of YKL-40 in sera and PE of patients with a variety of PE's.

\section{MATERIALS and METHODS}

\section{Study Design and Population}

We conducted a prospective, observational, cross-sectional and multidisciplinary study approved by the Ethics Committee of Ankara University and was designed in accordance with the Declaration of Helsinki. Between 01 September 2013 and 01 January 2014, 119 consecutive subjects with PE older than 18 years of age who gave written informed consent were enrolled in the study. Subjects with unclassified or undiagnosed PEs were excluded from the study.

All patients with PE were allocated into 5 groups based on clinical features, radiological examination 
and pleural fluid analysis: transudates (TPE), malignant PE (MPE), parapneumonic PE (PPPE), paramalignant PE (PME) and tuberculosis PE (TBPE). We differentiated exudates from transudates by using the Light's criteria and albumin and/or protein gradient was calculated when needed. MPE was diagnosed by the presence of malignant cells in the pleural fluid or tissue. If there was a malignant focus in the body, but no evidence of pleural invasion or the presence of malignant cells in the pleural fluid or tissue, exudative PE was classified as PME. The presence of PE in patients with community acquired pneumonia was defined as PPPE. The American Thoracic Society criteria were the basis for the diagnosis of pneumonia. Adenosine deaminase (ADA) was also measured in both specimens. Any patient with pleural ADA level of $>70 \mathrm{U} / \mathrm{L}$ or, Ziehl-Neelsen or Lowenstrain-Jensen culture positive in pleural fluid or, pleural biopsy showing granulomas with caseification necrosis or, sputum Acid-Fast Bacilli positive with concurrent PE, or pleural fluid consistent with clinical signs and symptoms of tuberculosis together with lymphocyte predominance in PE and good response to anti-tuberculosis treatment was diagnosed with TBPE.

\section{Laboratory Parameters and Preparation of the Samples}

All samples were collected within 24 hours of admission to hospital. All patients underwent thoracentesis under the aseptic technique and peripheral blood was drawn simultaneously. The routine hematologic and biochemical parameters [(total protein, lactate dehydrogenase (LDH), albumin and glucose] and ADA in the pleural fluid and blood samples were studied. Additionally, cytological examinations and cultures for common pathogens and Mycobacterium tuberculosis were performed in pleural fluid samples.

For YKL-40 analysis, blood and pleural fluid samples were centrifuged at $3.000 \mathrm{rpm}$ for 15 minutes at room temperature immediately after drawn. The supernatants were collected in clean test tubes and stored at $-80^{\circ} \mathrm{C}$ until YKL-40 analysis. The supernatants were dissolved and stored at $2-8^{\circ} \mathrm{C}$ for 24 hours before the analysis. YKL-40 protein concentrations were determined in sera and pleural fluids by using an enzyme-linked immunosorbent test (ELISA) specific kit (MICROVUE YKL-40 ElA Kit, Quidel, San Diego, USA) according to the manufacturer's instructions. All procedures were performed by an experienced clinical biochemist who was blinded to the clinical diagnoses.

\section{Statistical Analysis}

All statistical evaluations were performed via the Statistical Package for Social Sciences (SPSS), version 15 (SPSS Inc, Chicago, IL, USA). Results were presented as the mean \pm standard deviation $(\mathrm{SD})$, nonparametric variables were shown as median, minmax values and nominal variables were shown as subject number and percent (\%). Two groups were compared by Student $t$ test (for mean values) and Mann Whitney- $U$ test (for median values). The groups more than two were compared by ANOVA variance analysis (for mean values) and Kruskal Wallis test (for median values). Pearson Ki-Square or Fisher's exact tests were used for nominal variables. Serum YKL-40, pleural YKL-40, Pleural/Serum (P/S) YKL-40 ratio results were compared by using the receiver operator characteristics (ROC) analysis between transudate and exudate groups and between PPPE, MPE, PME, transudates and TBPE diagnostic groups. The area under the curve (AUC) was calculated with \%95 confidence intervals $(\mathrm{Cl})$. Youden Index was used to detect the cut-off of the parameters to establish the sensitivity and specificity of them. The continuous data were compared by Spearman's or Pearson's correlation analyses when appropriate. Any $\mathrm{p}$ value $<$ 0.05 was considered significant.

\section{RESULTS}

A total of 119 patients ( 77 males, 42 females, mean age $66.93 \pm 13.32$ years) with PE were included in the study, out of which were 23 transudates and 96 were exudates. Out of 96 patients with exudative PE, 47 were MPE, 26 were PPPE, 17 were PME and 6 were TBPE. The study groups were comparable in regard to age and gender. The characteristics of the study groups are shown in Table 1.

Our patients had comorbidities such as chronic obstructive pulmonary disease (COPD), asthma, neurological diseases, diabetes mellitus (DM), hypertension $(\mathrm{HT})$, chronic renal failure. Of note, although pleural YKL-40 levels did not differ in subjects with or without comorbidities, serum YKL-40 levels were significantly higher in such patients $(p<0.001)$. Additionally, PEs of 4 patients with PPPE group were positive for microorganisms. Pleural and serum YKL40 levels of these patients were higher and P/S YKL40 ratio was lower than the rest of all patients without any statistical significance. 
Table 1. Study subject characteristics

\begin{tabular}{|lccc|}
\hline Groups & $\mathbf{n}$ & Age (year) & Sex (Male/Female) \\
\hline TPE & 23 & $70.65 \pm 10.94$ & $16 / 7$ \\
MPE & 47 & $66.23 \pm 13.31$ & $27 / 20$ \\
PPPE & 26 & $67.67 \pm 14.32$ & $17 / 9$ \\
PME & 17 & $68.53 \pm 13.31$ & $12 / 5$ \\
TBPE & 6 & $59.83 \pm 20.47$ & $5 / 1$ \\
TOTAL & 119 & $66.93 \pm 13.32$ & $77 / 42$ \\
\hline TPE: Transudates, MPE: Malignant pleural effusion, PPPE: Parapneumonic pleural effusion, PME: Paramalignant pleural effusion, TBPE: Tuberculous \\
pleural effusion.
\end{tabular}

Table 2. Correlation analysis of pleural YKL-40, serum YKL-40 and pleura/serum YKL-40 ratio levels and various parameters

\begin{tabular}{|lcccc|}
\hline Parameters & & Pleural YKL-40 & Serum YKL-40 & Pleura/Serum YKL-40 \\
\hline Age & $\mathrm{r}$ & 0.03 & 0.5 & -0.5 \\
ESR $(\mathrm{mm} / \mathrm{h})$ & $\mathrm{p}$ & 0.704 & $\mathbf{0 . 0 0}$ & $\mathbf{0 . 0 0}$ \\
& $\mathrm{r}$ & 0.05 & 0.3 & -0.3 \\
Serum CRP $(\mathrm{g} / \mathrm{dL})$ & $\mathrm{p}$ & 0.65 & $\mathbf{0 . 0 1}$ & $\mathbf{0 . 0 1}$ \\
& $\mathrm{r}$ & 0.09 & 0.2 & -0.2 \\
Serum albumin $(\mathrm{g} / \mathrm{dL})$ & $\mathrm{p}$ & 0.33 & $\mathbf{0 . 0 2}$ & $\mathbf{0 . 0 2}$ \\
& $\mathrm{r}$ & -0.07 & -0.5 & 0.5 \\
Serum protein $(\mathrm{g} / \mathrm{dL})$ & $\mathrm{p}$ & 0.4 & $\mathbf{0 . 0 0}$ & $\mathbf{0 . 0 0}$ \\
& $\mathrm{r}$ & -0.0 & -0.2 & 0.2 \\
Pleura albumin $(\mathrm{g} / \mathrm{dL})$ & $\mathrm{p}$ & 0.77 & $\mathbf{0 . 0 1}$ & $\mathbf{0 . 0 3}$ \\
& $\mathrm{r}$ & 0.1 & -0.3 & 0.4 \\
Pleura protein $(\mathrm{g} / \mathrm{dL})$ & $\mathrm{p}$ & 0.08 & $\mathbf{0 . 0 0}$ & $\mathbf{0 . 0 0}$ \\
& $\mathrm{r}$ & 0.3 & -0.04 & 0.1 \\
Pleura LDH $(\mathrm{U} / \mathrm{L})$ & $\mathrm{p}$ & $\mathrm{0.01}$ & 0.61 & 0.09 \\
& $\mathrm{0}$ & $\mathbf{0 . 2}$ & 0.1 & 0.01 \\
\hline ESR: Erythrocyte sedimentation & rate, CRP: C-reactive & protein, LDH: Lactate dehydrogenase. & 0.12 & 0.9 \\
\hline
\end{tabular}

We examined the associations between YKL-40 levels and various parameters. We observed positive correlations between pleural YKL-40 levels with pleura protein and pleura LDH. Serum YKL-40 levels showed positive correlations with age, erythrocyte sedimentation rate (ESR) and serum C-reactive protein (CRP) levels and negative correlations with serum albumin, serum protein and pleura albumin. P/S YKL-40 ratio showed positive correlations with serum albumin, serum protein and pleura albumin (Table 2). Furthermore, P/S YKL-40 ratio and pleural ADA levels showed positive and significant correlation in TBPE group $(r=1, p=0.04)$ (Figure 1). However, in TBPE group and in all study population, there were no correlations between YKL-40 and ADA levels in PE and serum.
Pleural YKL-40 levels were 1.38-fold higher than that of serum in patients with PEs regardless of the diagnostic group $(\mathrm{p}<0.001)$. Pleural YKL-40 was found significantly higher in subjects with exudates than transudates $(p=0.01)$, but serum YKL-40 and P/S YKL40 ratio did not differ between two groups (Figure $2 \mathrm{a}$, $2 b, 2 c)$.

The highest pleural YKL-40 level was found in PME whereas the lowest in transudates as to be expected $(p=0.02)$ (Figure $2 d)$. The highest serum YKL-40 level was found in PPPE followed by PME, MPE, transudates and the lowest in TBPE $(p=0.01)$ (Figure 2e). $\mathrm{P} / \mathrm{S}$ YKL-40 ratios were similar among all patient groups (Figure $2 \mathrm{f}$ ). Median level of pleural and serum YKL-40 and $\mathrm{P} / \mathrm{S}$ ratio in transudates and exudates can 


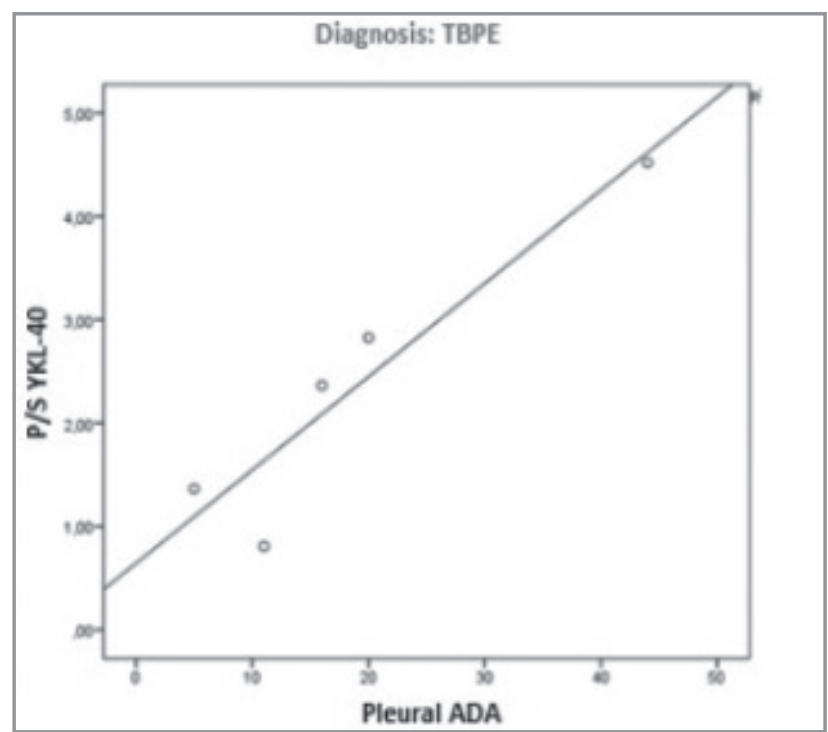

Figure 1. Correlation of pleural adenosine deaminase (ADA) and pleural/serum ratio YKL-40 (P/S YKL-40) in tuberculous pleural effusion (TBPE) group.
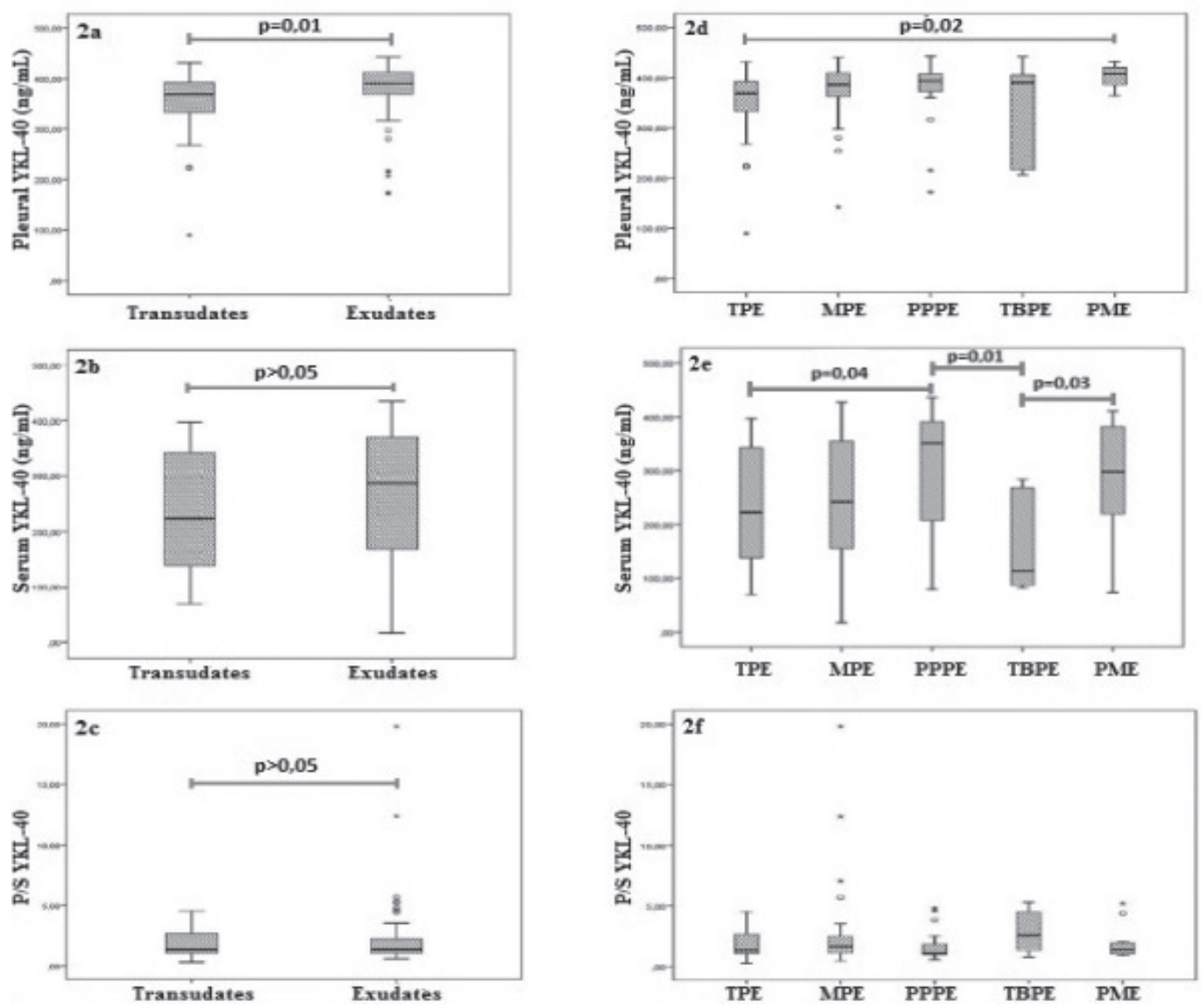

Figure 2. Boxplots of pleural YKL-40, serum YKL-40 and pleural/serum ratio YKL-40. 
Table 3. Pleural and serum YKL-40 levels and pleura/serum YKL-40 ratio in transudates and exudates

\begin{tabular}{|c|c|c|c|}
\hline Groups & Pleural YKL-40 (ng/mL) & Serum YKL-40 (ng/mL) & Pleura/Serum YKL-40 \\
\hline $\begin{array}{l}\text { Transudates } \\
\mathrm{n}=23\end{array}$ & $\begin{array}{c}369.5 \pm 79.3 \\
(89.35-431.39)\end{array}$ & $\begin{array}{l}223 \pm 112.2 \\
(70.1-396.8)\end{array}$ & $\begin{array}{c}1.38 \pm 1.22 \\
(0.3-4.5)\end{array}$ \\
\hline $\begin{array}{l}\text { Exudates } \\
\mathrm{n}=96\end{array}$ & $\begin{array}{l}\mathbf{3 9 0 . 3} \pm \mathbf{5 3 . 1} \\
(172.1-442.3)\end{array}$ & $\begin{array}{l}286 \pm 114.4 \\
(17.1-435.8)\end{array}$ & $\begin{array}{c}1.38 \pm 2.43 \\
(0.6-19.8)\end{array}$ \\
\hline $\begin{array}{l}\text { Total } \\
\mathrm{n}=119\end{array}$ & $\begin{array}{c}387.5 \pm 60.25 \\
(89.3-442.3)\end{array}$ & $\begin{array}{c}282.1 \pm 114.2 \\
(17.1-435.8)\end{array}$ & $\begin{array}{c}1.38 \pm 2.25 \\
(0.3-19.8)\end{array}$ \\
\hline
\end{tabular}

Table 4. Pleural and serum YKL-40 levels and pleura/serum YKL-40 ratio in different diagnostic groups

\begin{tabular}{|c|c|c|c|}
\hline Groups & $\begin{array}{c}\text { Pleural YKL-40 } \\
(\mathrm{ng} / \mathrm{mL})\end{array}$ & $\begin{array}{c}\text { Serum YKL-40 } \\
(\mathrm{ng} / \mathrm{mL})\end{array}$ & Pleura/Serum YKL-40 ‡ \\
\hline $\begin{array}{l}\text { TPE } \\
n=23\end{array}$ & $\begin{array}{c}\mathbf{3 6 9 . 5} \pm \mathbf{7 9 . 3} * \\
(89.35-431.39)\end{array}$ & $\begin{array}{l}223 \pm 112.2 \\
(70.1-396.8)\end{array}$ & $\begin{array}{c}1.38 \pm 1.22 \\
(0.3-4.5)\end{array}$ \\
\hline $\begin{array}{l}\text { MPE } \\
n=47\end{array}$ & $\begin{array}{c}386 \pm 52.7 \\
(142.5-440.3)\end{array}$ & $\begin{array}{l}241.9 \pm 116 \\
(17.1-427.1)\end{array}$ & $\begin{array}{l}1.6 \pm 3.3 \\
(0.5-19.8)\end{array}$ \\
\hline $\begin{array}{l}\text { PPPE } \\
n=26\end{array}$ & $\begin{array}{c}393 \pm 60.7 \\
(172.1-442.3)\end{array}$ & $\begin{array}{c}\mathbf{3 5 1 . 4} \pm \mathbf{1 1 0 . 1}^{\mathbf{}} \\
(79.4-435.8)\end{array}$ & $\begin{array}{c}1.08 \pm 1.15 \\
(0.6-4.8)\end{array}$ \\
\hline $\begin{array}{l}\text { PME } \\
n=17\end{array}$ & $\begin{array}{c}\mathbf{4 0 7 . 1} \pm \mathbf{2 2 . 5} \\
(364-432.1)\end{array}$ & $\begin{array}{c}297.7 \pm 111.4 \\
(73.6-410.5)\end{array}$ & $\begin{array}{c}1.42 \pm 1.2 \\
(0.9-5.2)\end{array}$ \\
\hline $\begin{array}{l}\text { TBPE } \\
n=6\end{array}$ & $\begin{array}{c}389.63 \pm 102.5 \\
(206.8-441.2)\end{array}$ & $\begin{array}{c}\mathbf{1 1 4 . 2} \pm \mathbf{9 3 . 4 8}^{\mathbf{}} \\
(82.7-284)\end{array}$ & $\begin{array}{c}2.59 \pm 1.76 \\
(0.8-5.3)\end{array}$ \\
\hline $\begin{array}{l}\text { Total } \\
n=119\end{array}$ & $\begin{array}{c}387.5 \pm 62.3 \\
(89.4-442.3)\end{array}$ & $\begin{array}{c}280.5 \pm 115.7 \\
(17.1-435.8)\end{array}$ & $\begin{array}{l}1.4 \pm 2.29 \\
(0.3-19.8)\end{array}$ \\
\hline \multicolumn{4}{|c|}{$\begin{array}{l}\text { TPE: Transudates, MPE: Malignant pleural effusion, PPPE: Parapneumonic pleural effusion, PN } \\
\text { pleural effusion. } \\
\text { * The lowest pleural YKL-40 level was in TPE group and the highest in PME group }(p=0.02) \text {. } \\
\text { + The lowest serum YKL-40 level was in TBPE group and the highest in PPPE group }(p=0.01 \text { ). } \\
\text { ₹ There was no significant difference for pleura/serum YKL-40 ratio between the groups. }\end{array}$} \\
\hline
\end{tabular}

also been seen in Table 3 and those of the diagnostic groups in Table 4.

For the evaluation of the diagnostic performance of YKL-40 levels, ROC analysis was performed. At 378 $\mathrm{ng} / \mathrm{mL}$ cut-off level, pleural YKL-40 could differentiate exudates from transudates with $70 \%$ sensitivity and $64 \%$ specificity, with an AUC of $0.660(p=0.01)$ (Figure 3a). At $396 \mathrm{ng} / \mathrm{mL}$ cut-off level, it could differentiate PME from other subgroups with $65 \%$ sensitivity and $68 \%$ specificity, with an AUC of $0.680(\mathrm{p}=$ 0.02) (Figure 3b).

Serum YKL-40 level did not distinguish exudates from transudates, however, for a cut-off level of $356 \mathrm{ng} /$ $\mathrm{mL}$, high level of serum YKL-40 could differentiate PPPE from other subgroups with $50 \%$ sensitivity and $75 \%$ specificity and with an AUC of $0,640(p=0.03)$
(Figure 4a). Low serum YKL-40 level could differentiate TBPE from other subgroups, for a cut-off level of $284 \mathrm{ng} / \mathrm{mL}$, with $100 \%$ sensitivity and $50 \%$ specificity, with an AUC of $0.770(p=0.02)$ (Figure $4 b)$. At $284 \mathrm{ng} / \mathrm{mL}$ cut-off level of serum YKL-40 could also differentiate PPPE and TBPE with $61 \%$ sensitivity and $100 \%$ specificity, with an AUC of $0.830(p=0.01)$ (Figure 4c). The details of the ROC analyses were shown in Table 5.

\section{DISCUSSION}

The differential diagnosis of PE is a challenging clinical problem. In some cases, a definite diagnosis cannot be made despite all examinations. Therefore, some patients with PEs are misdiagnosed, so inappropriate treatment is applied delaying the diagnosis of the actual disease. For this reason, in recent years, 

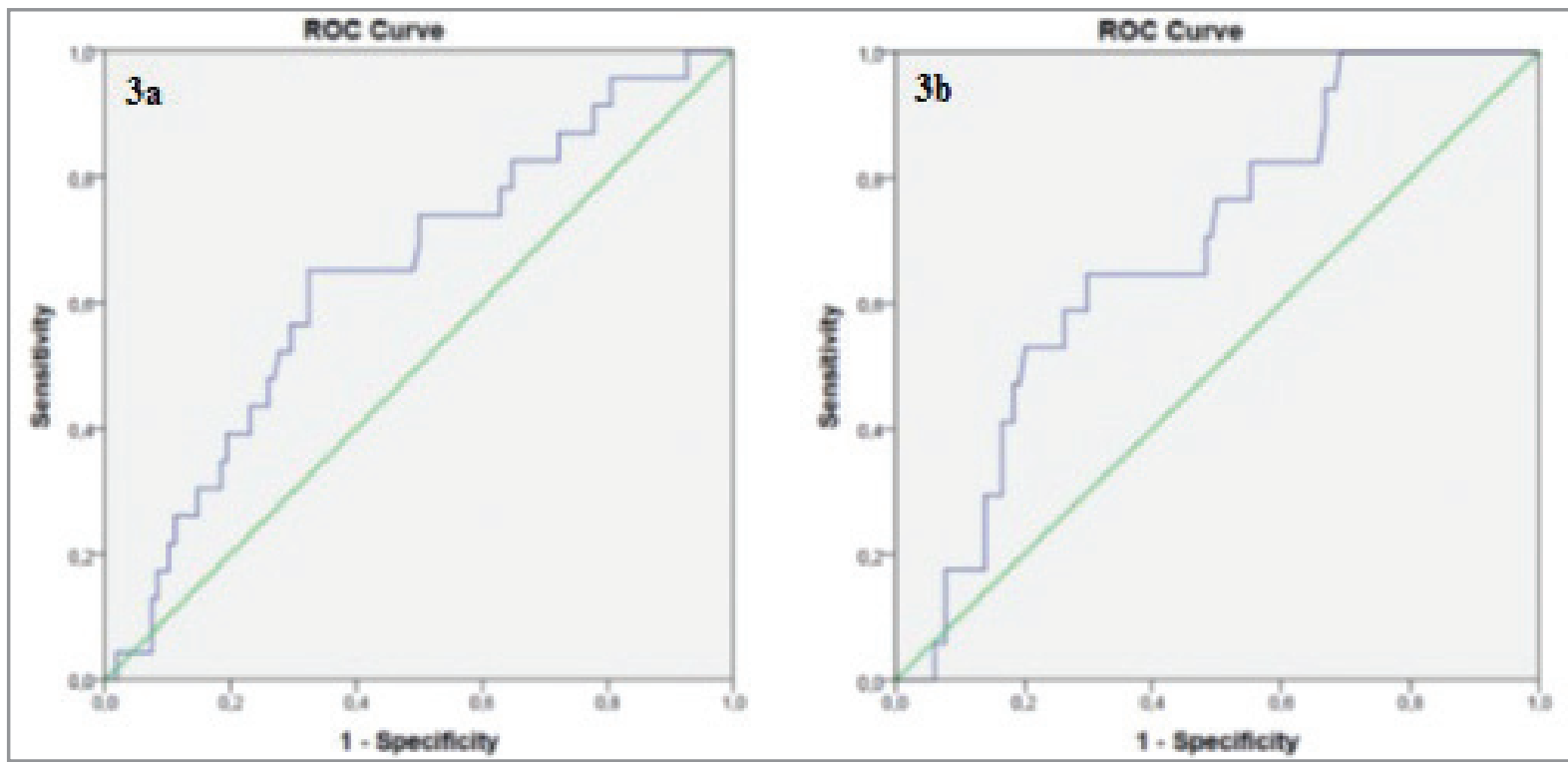

Figure 3. Receiver operator characteristic (ROC) analysis curves, depicting the specificity and the sensitivity of pleural YKL-40.
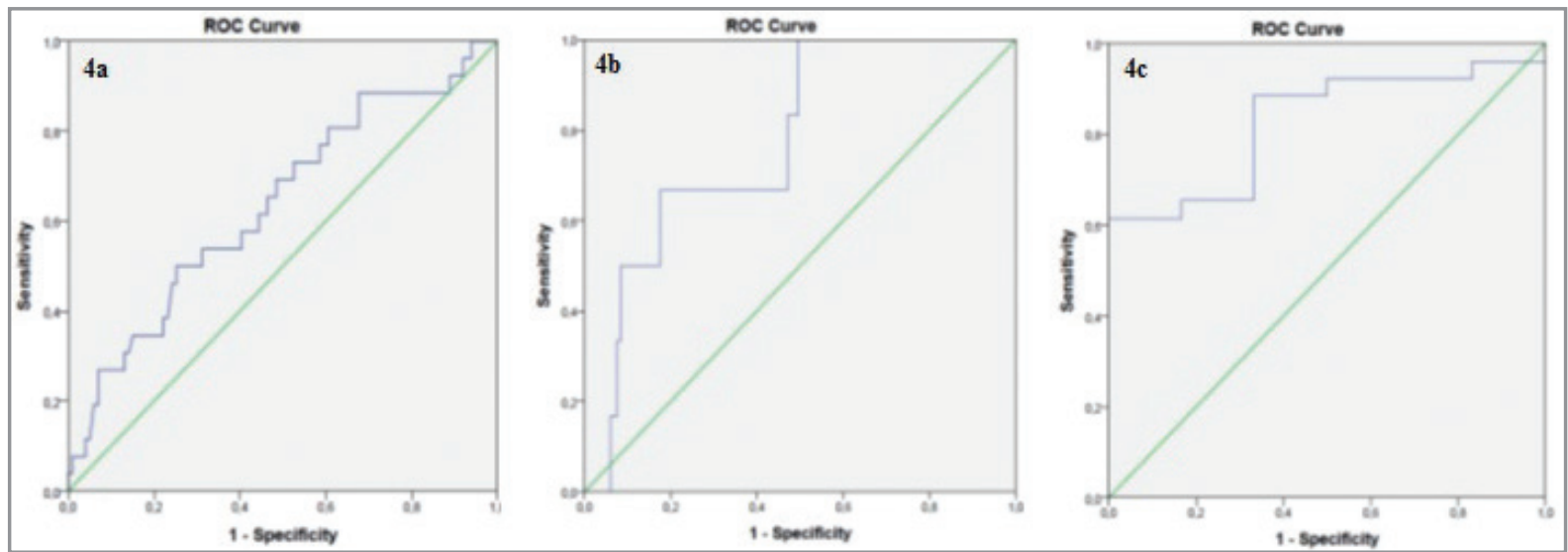

Figure 4. Receiver operator characteristic (ROC) analysis curves, depicting the specificity and the sensitivity of serum YKL-40.

Table 5. Receiver-operating characteristic (ROC) analyses of pleural YKL-40 and serum YKL-40

\begin{tabular}{|c|c|c|c|c|c|c|}
\hline Parameters & Groups & Cut-off level (ng/ml) & Sensitivity (\%) & Specificity (\%) & AUC & $\mathbf{p}^{*}$ \\
\hline \multirow[t]{2}{*}{ Pleural YKL-40 } & Exudates-Transudates & 378 & 70 & 64 & 0.660 & 0.01 \\
\hline & PME-other subgroups & 396 & 65 & 68 & 0.680 & 0.02 \\
\hline \multirow[t]{6}{*}{ Serum YKL-40 } & PPPE-other subgroups & 356 & 50 & 75 & 0.640 & 0.03 \\
\hline & TBPE-other subgroups & 284 & 100 & 50 & 0.770 & 0.02 \\
\hline & PPPE-TBPE & 284 & 61 & 100 & 0.830 & 0.01 \\
\hline & PME-TBPE & 286 & 58 & 100 & 0.804 & 0.03 \\
\hline & PPPE-Transudates & 356 & 50 & 81 & 0.680 & 0.04 \\
\hline & PPPE-MPE & 356 & 50 & 76 & 0.660 & 0.04 \\
\hline
\end{tabular}

AUC: Area under the curve, PME: Paramalignant pleural effusion, PPPE: Parapneumonic pleural effusion, TBPE: Tuberculous pleural effusion, PPPE: Parapneumonic pleural effusion, MPE: Malignant pleural effusion.

$* p$ values $<0.05$ were accepted as significant. 
many biomarkers including YKL-40 have been investigated for the differential diagnosis of PEs.

In the present study, we measured YKL-40 levels in pleural fluids and sera, in order to demonstrate the correlation with its circulating levels in peripheral blood, and to determine the diagnostic value of this molecule in the differential diagnoses of PEs. Until today, only 5 studies have investigated pleural YKL40 (4-8). The most remarkable results of these studies, including ours, is that high pleural YKL-40 levels are sensitive in discriminating exudates from transudates.

In two studies investigating healthy subjects, indicated that YKL-40 increased with age, probably due to low level of inflammation in elderly, and found no relationship with gender $(9,10)$. Compatible with the previous studies, we found a weak but significant correlations with age and serum YKL-40 and there was no significant relation with gender. In our study, serum YKL-40 showed inverse correlations with serum albumin and serum protein which decreases by inflammation as an acute phase reaction. This is also supported by the fact that serum CRP and ESH indicating inflammation, show positive correlations with YKL-40.

Serum YKL-40 has been evaluated in considerable amount of asthma and COPD patients and has been found associated with asthma severity, COPD mortality and reduced lung functions and $\mathrm{PaO}_{2}$ values (1114). In a recent meta-analysis, they further confirmed that both levels of serum and sputum YKL-40 were increased in patients with COPD, and that these elevated levels were significantly correlated with disease status and lung function (15). Serum YKL-40 was also found higher in DM type 1 and 2 patients and associated with the complication of the disease, suggesting inflammation in all these diseases (16-18). In our PE patients with concomitant diseases, serum YKL-40 was significantly higher, suggesting that YKL40 indicated the presence of systemic inflammation.

Serum YKL-40 is elevated in chronic inflammation as well as in pathogen-induced inflammation, such as endotoxemia caused by purulent meningitis, pneumonia and E. coli toxin. Locally active macrophages and neutrophils in pneumonia release YKL-40 (1), it can be increased in streptococcal pneumonia, decreased by antibiotic treatment and YKL-40 level in bacteremia is related to disease severity and prognosis $(1,19)$. Nordanbaek et al. investigated 90 pneumonia patients on admission to the hospital and serum YKL-40 levels were significantly higher in subjects with Streptococcus pneumonia when compared to healthy control subjects. They suggested that active neutrophils releasing granules were the main source of this biomarker in acute bacterial pneumonia (20). A recent study also found a similar result and suggested that higher levels of YKL-40 in more severe pneumonia, possibly reflecting the degree of pulmonary inflammation (21). Similarly, we also found a significantly higher YKL-40 level in PPPE subjects. However, as we did not re-measure in the course of disease, we cannot recommend it as a follow-up measurement.

Kim et al. found the highest serum YKL-40 level in pneumonia group followed by tuberculosis, COPD, cancer, asthma and control group (4). In the study by Kayhan et al. serum YKL-40 level was the highest in PPPE (5). Similarly, we found the highest serum YKL40 level in PPPE followed by PME, MPE, transudates and TBPE.

In three of the previous studies, the lowest serum YKL-40 levels were in TBPE, probably because of the youngest age of such patients (5-7). Adamidi et al. suggested that serum YKL-40 could be a good marker to distinguish tuberculosis from other causes of PEs (6). Similarly, we found the lowest serum YKL-40 level in TBPE regardless the age of the subjects. In addition, low levels of serum YKL-40 were found to be significantly different between TBPE and PPPE and PME. Our ROC analyses also showed that high level of YKL-40 favours PPPE and low level favours TBPE with a high sensitivity and specificity. This suggests that low levels of serum YKL-40 may contribute to our daily practice in differentiating TBPE from PPPE and PME.

Pleural YKL-40 did not show a significant relation with age and gender. However, in agreement with previous studies findings, pleural YKL-40 showed positive correlations with pleura protein and pleura $\mathrm{LDH}$. They suggested that the increased levels of both markers (LDH and YKL-40) in pleural fluid may be secondary to increased local production either through increased cellular destruction, local invasion or tissue irritation $(5,7)$.

Pleural YKL-40 level was found lower in the transudate group than in all other groups, except in one study. Adamidi et al. found no significant difference between the diagnostic groups which was attributed to the presence of many comorbidities in subjects 
with transudates because of the associated high serum YKL-40 level (6). However, other studies reported a moderate sensitivity and specificity for pleural YKL-40 to differentiate exudates from transudates $(5,7)$. In agreement with these results we also found a moderate sensitivity and specificity of pleural YKL-40 level at $378 \mathrm{ng} / \mathrm{mL}$ in which high levels indicated exudates whereas low levels indicated transudates. These results suggest that this measurement may be used as a parameter in differentiating PEs.

In our study, the highest pleural YKL-40 level was found in PME followed by PPPE, TBPE, MPE and transudates. In the previous studies, the highest pleural YKL-40 value was measured in TBPE and in MPE, but there was no significant difference between the diagnostic groups in one of the study $(4,6-8)$. At a threshold value of $396 \mathrm{ng} / \mathrm{mL}$, we observed that pleural YKL-40 could distinguish PMEs from other groups with a moderate sensitivity and specificity. As our study is the first to investigate PME subjects, we are unable to compare our results with previous studies. The second highest pleural YKL-40 level was in PPPE. In our study, 4 of the 27 PPPE cases were positive on culture. This is the first study to evaluate pleural YKL40 in culture positive PPPE. However, due to the limited number of cases no significant relation could be found between the culture positivity and YKL-40 level.

Attia et al. reported significantly higher YKL-40 levels in MPE. They attributed this high level of pleural YKL40 to increased local production of YKL-40 by neoplastic cells (7). Shahanaze et al. also found that the level of pleural YKL-40 was significantly elevated in MPEs (8). However, Kayhan et al. found no significant difference between malignant and non-malignant cases of pleural YKL-40 (5). In the present study, although not significant, we found low levels of pleural YKL-40 in MPEs. Pleural YKL-40 levels could be a helpful biomarker for differential diagnosis of MPE, but we did not find enough sensitivity and specificity to differentiate MPEs and non-malignant PEs. To clarify the issue of conflict in this regard further evaluation of contemporary pleural cytology and YKL-40 studies are warranted.

A recent study reported a significant relationship between pleural ADA and chitotriosidase activity in TBPEs and nontuberculous PEs (22). In the present study, while pleural and serum YKL-40 levels did not show any correlations between ADA levels, pleural
ADA levels strongly correlated with P/S YKL-40 ratio in TBPEs, suggesting that this can be a reliable diagnostic tool in such patients. The previous studies did not confirm this relationship but they reported high P/S YKL-40 ratio could separate TBPE from nontuberculous PEs (5-7). Similarly, we found the highest ratio of P/S YKL-40 in TBPEs. However, this high ratio could not differentiate TBPE from nontuberculous PEs in our study.

YKL-40 is released from macrophages, neutrophils, airway epithelial cells and fibroblastic mesothelial cells. These cells are involved in the etiology of TBPE, PPPE and MPE. For this reason, although the mechanism is not fully known, it is suggested that these 4 cell types or combinations are the source of YKL-40 in exudates. Literature data and our results suggest that pleural YKL-40 is excreted both in the serum and in the microvasculature of the inflated pleural space.

In conclusion, by the findings of our study which is one of the leading researches in the field, we suggest that serum and pleural YKL-40 levels are valuable parameters in differential diagnosis in PEs. Further researches are warranted to on this topic to develop new diagnostic and therapeutic strategies and we hope that our study will help shedding light on future investigations.

\section{ACKNOWLEDGEMENT}

This study was supported by the Scientific Research Projects (BAP) of Ankara University (Project No: BAP13H3330006).

Ethics Committee Approval: The approval for this study was obtained from Ankara University School of Medicine Clinical Research Ethics Committee (Decision no: 09-354-13 Date: 27.05.2013).

\section{CONFLICT of INTEREST}

The authors report no conflict of interest.

\section{AUTHORSHIP CONTRIBUTIONS}

Concept/ Design: YS, OK

Analysis/Interpretation: All of authors

Data Acquisition: YS

Writing: YS, OK

Critical Revision: YS, OK

Final approval: All of authors 


\section{REFERENCES}

1. Kzhyshkowska J, Gratchev A, Goerdt S. Human chitinases and chitinase-like proteins as indicators for inflammation and cancer. Biomark Insights 2007; 2: 128-46.

2. Thöm I, Andritzky B, Schuch G, Burkholder I, Edler L, Johansen JS, et al. Elevated pretreatment serum concentration of YKL-40-an independent prognostic biomarker for poor survival in patients with metastatic nonsmall cell lung cancer. Cancer 2010; 116: 4114-21.

3. Lee CG, Da Silva CA, Dela Cruz CS, Ahangari F, Ma B, Kang MJ, et al. Role of chitin and chitinase/chitinase-like proteins in inflammation, tissue remodeling, and injury. Annu Rev Physiol 2011; 73: 1-28.

4. Kim $H R$, Jun $C D$, Lee $K S$, Cho $J H$, Jeong $E T$, Yang $S H$, et al. Levels of YKL-4O in pleural effusions and blood from patients with pulmonary or pleural disease. Cytokine 2012; 58(3): 336-43.

5. Kayhan S, Gumus A, Cinarka H, Murat N, Yilmaz A, Bedir $R$, et al. The clinical utility of pleural YKL-40 levels in diagnosing pleural effusions. J Thorac Dis 2013; 5: 634-40.

6. Adamidi T, Soulitzis N, Neofytou E, Zannetos S, Georgiou A, Benidis K, et al. Expression of YKL-40 and MIP-1a proteins in exudates and transudates: biomarkers for differential diagnosis of pleural effusions? a pilot study. BMC Pulm Med 2015; 15(150): 1-9.

7. Attia A, Rasmy A, Amin A, Alanazi M. Evaluation of pleural fluid YKL-40 as a marker of malignant pleural effusion. Egypt J Chest Dis Tuberc 2015; 64(2): 489-95.

8. Shahanaze $\mathrm{H}$, Jayachandran S, Madhusmita MM, Soundravally R. Clinical utility of pleural fluid YKL-40 as a marker of malignant pleural effusion. Curr Probl Cancer 2019; 43: 354-62.

9. Schmidt H, Johansen JS, Gehl J, Geertsen PF, Fode K, Maase $H$. Elevated serum level of YKL-4O is an independent prognostic factor for poor survival in patients with metastatic melanoma. Cancer 2006; 106(5): 1130-9.

10. Bojesen S, Johansen J, Nordestgaard B. Plasma YKL-40 levels in healthy subjects from the general population. Clin Chim Acta 2011; 412(9-10): 709-12.

11. Chupp GL, Lee C, Jarjour N, Shim YM, Holm CT, He S, et al. A chitinase-like protein in the lung and circulation of patients with severe asthma. N Engl J Med 2007; 357(20): 2016-27.
12. Holmgaard DB, Mygind LH, Titlestad IL, Madsen $H$, Pedersen SS, Johansen JS, et al. Plasma YKL-40 and allcause mortality in patients with chronic obstructive pulmonary disease. BMC Pulm Med 2013; 13: 77.

13. Gumus A, Kayhan S, Çınarka H, Kırbaş A, Bulmuş $N$, Yavuz $A$, et al. High serum YKL-4O Level in patients with $C O P D$ is related to hypoxemia and disease severity. Tohoku J Exp Med 2013; 229(2): 163-70.

14. James AJ, Reinius LE, Verhoek M, Gomes A, Kupczyk M, Hammar U, et al. Increased YKL-40 and chitotriosidase in asthma and chronic obstructive pulmonary disease. Am J Respir Crit Care Med 2016; 193(2): 131-42.

15. Tong $X$, Tian P. The YKL-40 protein is a potential biomarker for COPD: a meta-analysis and systematic review. Int I Chronic Obstr Lung Dis 2018; 13: 409-18.

16. Rathcke CN, Johansen JS, Vestergaard H. YKL-40, a biomarker of inflammation, is elevated in patients with type 2 diabetes and is related to insulin resistance. Inflamm Res 2006; 55: 53-9.

17. Rathcke CN, Persson F, Tarnow L, Rossing P, Vestergaard H. YKL-40, a marker of inflammation and endothelial dysfunction, is elevated in patients with type 1 diabetes and increases with levels of albuminuria. Diabetes Care 2009; 32(2): 323-8.

18. Han JY, Ma XY, Yu LI, Shao Y, Wang QY. Correlation between serum YKL-40 levels and albuminuria in type 2 diabetes. Genet Mol Res 2015; 14(4): 18596-603.

19. Duru S, Yüceege $M$, Ardiç S. Chitinases and lung diseases. Tuberk Toraks 2013; 61(1): 71-5.

20. Nordenbaek C, Johansen IS, Junker P, Borregaard N, Sørensen O, Price PA. YKL-40, a matrix protein of specific granules in neutrophils, is elevated in serum of patients with community-acquired pneumonia requiring hospitalization. J Infect Dis 1999; 180: 1722-6.

21. Spoorenberg SM, Vestjens S, Rijkers G, Meek B, Moorsel C, Gruttels J, et al. YKL-40, CCL18 and SP-D predict mortality in patients hospitalized with community-acquired pneumonia. Respirology 2017; 22(3): 542-50.

22. Bouzas L, San Jose E, Tutor J. Chitotriosidase activity in pleural effusions. Clin Lab 2007; 53: 449-52. 